\title{
PENGARUH MANAJEMEN PERAWATAN SISTEM ENGKOL TERHADAP PENGOPERASIAN MESIN ANGLO BELGIAN CORPORATION TYPE 12V
}

\author{
B. J Camerling \\ Program Studi Teknik Industri, Fakultas Teknik Universitas Pattimura, Ambon \\ D. B. Paillin \\ Program Studi Teknik Industri, Fakultas Teknik Universitas Pattimura, Ambon \\ Adha B Dharma \\ PLN Wilayah Maluku dan Maluku Utara, Ambon
}

\begin{abstract}
ABSTRAK
Peranan perawatan terhadap mesin diesel engine pada bagian maintenance PLTD sangat penting artinya untuk mencegah terjadinya down time produksi, dan perawatan yang paling baik digunakan adalah perawatan pencegahan sebelum terjadinya kerusakan (preventive maintenance). Sistem perawatan mesin yang dilakukan di PLTD Poka, ialah periodic maintenance dan condition-based maintenance yaitu tindakan perawatan yang dilakukan berdasarkan lamanya waktu operasi mesin yang telah ditentukan oleh pabrikan dan berdasarkan kondisi mesin. Dengan sistem tersebut, ditemukan kesulitan perencanaan dan administrasi pemeliharaan karena fluktuatifnya pengoperasian mesin sehingga pemeliharaan sering tidak tepat waktu. Waktu antar kerusakan adalah selang waktu terjadinya kerusakan setelah dilakukan perbaikan. Untuk menentukan waktu antar kerusakan, langkah pertama yang dilakukan adalah dengan mengukur lamanya waktu operasi mesin setelah dilakukan perbaikan pada setiap kerusakan mesin. Sistem perencanaan pemeliharaan selama ini masih menggunakan perhitungan pecatatan yang dilakukan secara manual sehingga ada kemungkinan salah perhitungan perencanaan pemeliharaan yang berujung pada tidak tercapainya SFC, SLC dan Jam operasi Mesin yang diharapkan/ditargetkan. Berdasarkan permasalahan tersebut, maka perlu dilakukan perawatan terhadap poros engkol sehingga bisa mencegah kerusakan yang lebih parah sehingga bisa tercapai pengoperasian mesin yang maksimal dan efisien. Penggunaan RCM diperlukan pada perawatan mesin ini sehingga hasil yang didapatkan untuk perawatan mesin lebih optimal dibandingkan dengan perawatan mesin yang dilakukan saat ini.
\end{abstract}

Kata Kunci: Pemeliharaan. Poros Engkol, Pembangkit Listrik Diesel, RCM, FMEA.

\begin{abstract}
The role of maintenance of the Diesel Engine on the PLTD maintenance departed is important to prevent downtime production. The best treatment used is preventive maintenance. The engine maintenance system that carried out on PLTD Poka was a periodic maintenance and condition-based maintenance which means an action that is based on the length of operation time according to manufacturer manual and condition of the machine. With this system, it is difficult to find a periodic plan to maintain the machine due to the fluctuating operation. Interarrival time is the interval time between damage and reparation. To determine the interarrival time firstly is by measuring the length of operation time after repairing every damage. So far, the maintenance plan system is done by manual record thus there is a miscalculation of maintenance plan system as the results in the non-achievement of SFC, SLC, and expected operation time. Through this experience, it is important to maintain crankshaft in order to prevent severe damage so that the efficient engine operation could be obtained. The use of RCM is required in the engine maintenance so that the result will be optimum compare to the recent machine maintenance
\end{abstract}

Keywords: Maintenance, crankshaft, diesel power plant, RCM, FMEA

\section{PENDAHULUAN}

Sistem manajemen perawatan merupakan hal yang sangat penting untuk diterapkan didunia industri, maka keadaan tersebut memaksa suatu perusahaan untuk lebih meningkatkan kelancaran, efektivitas dan efisiensi kegiatan operasinya. Salah satu hal yang mendukung kelancaran kegiatan operasi pada suatu perusahaan adalah kesiapan mesin atau peralatan dalam melaksanakan tugasnya. Untuk menjaga tingkat 
kesiapan mesin atau peralatan agar mesin atau peralatan dapat selalu digunakan, maka dibutuhkan perawatan mesin atau maintenance yang baik.

Energi listrik memegang peranan penting dalam perkembangan peradaban manusia saat ini. Hal ini dapat dilihat dala konsumsi listrik yang makin meningkat sering peningkatan kebutuhan hidup. Penggunaan alat - alat elektronik rumah tangga, ertambahan perusahan dan industri serta pembangunan infrastruktur pemerintah membutuhkan suplay listrik. Peningkatan kebutuhan ini mempengaruhi kinerja sistem pembangkit dalam menyuplai energi listrik, performasi mesin untuk memberikan pasokan listrik menjadi faktor prioritas yang perlu diperhatikan. Produktifitas mesin dalam beroperasi memiliki limit pemakaian efesiensi penggunaan secara kontinyu sehingga untuk terus menjaga dan mempertahankan daya guna mesin, serta mencegah dan memperbaiki kerusakan selama operasi dibutuhkan perawatan mesin.

Pusat listrik poka menjadi pusat pembangkit terbesar di Maluku dengan 7 unit pembangkit listrik masing - masing mesin GMT 3 unit, Mesin Caterpilar sebanyak 2 unit sera mesin Anglo Belgian Comporation (ABC) sebanyak 2 unit. Mesin Anglo Belgian Comporatio (ABC) tipr mesin 12V DZC dioperasikan oleh pembangkit listrik pada bulan sebtember 2005 memiliki tatatan kerja di dasarkan sesuai kondisi ISO (ISO 3046-I), sejak operasi mesin ABC terus mengalami perawatan harian dan berskala untuk menjaga stabilisasi mesin dalam memberikan pelayanan konsumsi listrik masyarakat kota ambon dan sekitarnya. Namun demikian, perawatan jenis preventive yang dilaksanakaan oleh pusat listrik poka tidak memperhatikan jam operasional secara lebih disiplin sehingga waktu perawatan komponen komponen dengan interval perawatan yang lebih jau hanya berdasarkan perkiraan tanpa perhitungan waktu yang pasti. Hal in tentu saja berdampak performansi mesin yang memiliki Standar Opertional Procedure dalam tiap tahap perawatannya hingga berujung pada pelayanan jasa yang kurang memuaskan.

Heizer dan Render (2006) mendefenisikan Mainteinence adalah semua aktifitas yang berkaitan untuk mempertahankan peralatan system dalam kondisi yang layak bekerja, system perawatan yang baik menghilangkan variabilitas system. Perawatan di suatu industry merupakan salah satu faktor yang penting dalam mendukung suatu proses produksi yang mempunyai daya saing di pasaran. Tidak hanya berpengaruh pada efesiensi kerja mesin/peralatan tersebut tetapi juga devisit anggaran yang akan di keuarakan perusahan dalam menangani masalah proses produksinya. Tindakan servis yang direkomendasikan harus dilakukan pada interval yang sesuai, lingkungan pengoperasian engine yang actual juga mengatur jadwal perawatan periodic, dengan demikan pada kondisi pengoperasian ekstrim yang parah, berdebu, basah, atau membeku akan diperlukan tindakan perawatan yang lebih sering daripada yang ditentukan. Implementasi program menajemen perawatan pencegahan harus meminimalakan biaya yang timbul akibat mogok yang direncanakan sertakerusakan. Maka dapat di simpulkan Maintenance management merupakan segalah aktifitas yang dilakakuan dalam upaya mempertahankan dan memperbaiki kondisi fisik fasilitas agar tetap beradah pada kondisi layak pakai.

Pada penelitian ini digunakan metode RCM yaitu untuk menentukan kegiatan perawatan yang optimal bagi perusahan. RCM merupakan serangkai proses yang digunakan untuk menentukan apa yang harus dilakukan untuk memastikan bahwa asset - asset fisik dapat berjalan baik dalam menjalankan fungsi yang dikehendaki oleh pemakainya dalam hal ini adalah perusahan. Penelitian ini bertujuan untuk mengethui komponen-komponen kritis pada sistem engkol, menentukan rencana kegiatan perawatan dalam mengantisipasi adanya kegaggalan atau kerusakan yang terjadi pada sistem engkol dan mengetahui pengaruh manajemen perawatan sistem engkol pada mesin ABC type $12 \mathrm{~V}$.

\section{LANDASAN TEORI}

\section{Pengertian Pemeliharaan atau Maintenance}

Maintenance merupakan suatu fungsi dalam suatu industri manufaktur yang sama pentingnya dengan fungsi-fungsi lain seperti produksi. Hal ini karena apabila kita mempunyai mesin/peralatan, maka biasanya kita selalu berusaha untuk tetap dapat mempergunakan mesin/peralatan sehingga kegiatan produksi dapat berjalan lancer (Arsyad dan Sultan, 2018). Dalam usaha untuk dapat menggunakan terus mesin/peralatan agar kontinuitas produksi dapat terjamin, maka dibutuhkan kegiatan kegiatan pemeliharaan dan perawatan yang meliputi:

1. Kegiatan pengecekan.

2. Meminyaki (lubrication).

3. Perbaikan/reparasi atas kerusakan-kerusakan yang ada.

4. Penyesuain/penggantian spare part atau komponen. 
Beberapa tujuan utama dari maintenance atau pemeliharaan adalah sebagai berikut:

1. Kemampuan berproduksi dapat memenuhi kebutuhan sesuai dengan rencana produksi.

2. Menjaga kualitas pada tingkat yang tepat untuk memenuhi apa yang dibutuhkan oleh produk itu sendiri dan kegiatan produksi yang tidak terganggu.

3. Untuk membantu mengurangi pemakaian dan penyimpangan yang diluar batas dan menjaga modal yang diinvestasikan dalam perusahaan selama waktu yang ditentukan sesuai dengan kebijakan perusahaan mengenai investasi tersebut.

4. Untuk mencapai tingkat biaya maintenance secara efektif dan efisien keseluruhannya.

5. Untuk menjamin keselamatan orang yang menggunakan sarana tersebut.

6. Memaksimumkan ketersedian semua peralatan sistem produksi (mengurangi downtime).

7. Untuk memperpanjang umur/masa pakai dari mesin/peralatan.

Tugas dan fungsi dari maintenance atau pemeliharaan adalah sebagai berikut:

1. Mengevaluasi dan menyimpan data hasil perawatan (maintenance) dan spesifikasi material dari suatu proyek dalam sebuah dokumen pemeliharaan.

2. Melakukan koordinasi dan pengawasan terhadap upaya untuk mendapatkan ijin pelaksanaan perawatan fasilitas operasi dari instansi pemerintah yang berwenang (statutory equipment).

3. Mengadakan pengawasan kegiatan maintenance peralatan, dilapangan pada tahap pabrikasi maupun konstruksi.

4. Pada tahap comissioning terlibat dengan fungsi terkait melakukan pemeriksaan secara menyeluruh terhadap semua obyek konstruksi dan inventarisasi dokumen pendukung maintenance.

5. Melaksanakan maintenance peralatan secara rutin sesuai prosedur dan cara yang tepat dan benar.

6. Memberikan umpan balik kepada engineering/perekayasa untuk kepentingan perancangan untuk masa yang akan datang.

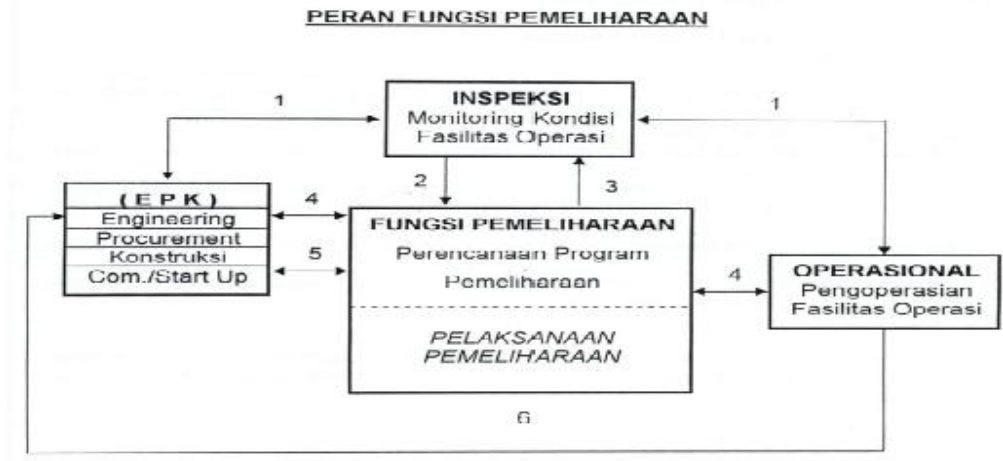

Peran Fungsi Pemeliharaan

Berikut ini adalah beberapa jenis-jenis maintenance atau pemeliharaan:

A. Planned Maintenance (Pemeliharaan Terencana)

Planned maintenance (pemeliharaa terencana) adalah pemeliharaan yang terorganisir dan dilakukan dengan pemikiran ke masa depan, pengendalian dan pencatatan sesuai dengan rencana yang telah ditentukan sebelumnya. Oleh karena itu program maintenance yang akan dilakukan harus dinamis dan memerlukan pegawasan dan pengendalian secara aktif dari bagian maintenance melalui informasi dari catatan riwayat mesin/peralatan.

Konsep planned maintenance ditujukan untuk dapat mengatasi masalah yang dihadapi manajer dengan pelaksanaan kegiatan maintenance. Komunikasi dapat diperbaiki dengan informasi yang dapat memberi data yang lengkap untuk mengambil keputusan. Adapun data yang penting dalam kegiatan maintenance antara lain laporan permintaan pemeliharaan, laporan pemeriksaan, laporan perbaikan, dan lain-lain. Pemeliharaan terencana (planned maintenance) terdiri dari tiga bentuk pelaksanaan, yaitu:

B. Preventive Maintenance (Pemeliharaan Pencegahan).

Preventive maintenance adalah kegiatan pemeliharaan dan perawatan yang dilakukan untuk mencegah timbulnya kerusakan-kerusakan yang tidak terduga dan menemukan kondisi atau keadaan yang dapat menyebabkan fasilitas produksi mengalami kerusakan pada waktu digunakan dalam proses produksi. Dengan demikian semua fasilitas produksi yang diberikan preventive maintenance akan terjamin kelancarannya dan selalu diusahakan dalam kondis atau keadaan yang siap dipergunakan untuk setiap operasi atau proses produksi pada setiap saat. Sehingga dapatlah dimungkinkan pembuatan suatu rencana dan jadwal pemeliharaan dan perawatan yang sangat cermat dan rencana produksi yang lebih tepat. 
C. Corrective Maintenance (Pemeliharaan Perbaikan)

Corrective maintenance adalah suatu kegiatan maintenance yang dilakukan setelah terjadinya kerusakan atau kelalaian pada mesin/peralatan sehingga tidak dapat berfungsi dengan baik.

D. Predictive Maintenance (Pemeliharaan Prediktif)

Predictive maintenance adalah tindakan-tindakan maintenance yang dilakukan pada tanggal yang ditetapkan berdasarkan prediksi hasil analisa dan evaluasi data operasi yang diambil untuk melakukan predictive maintenance itu dapat berupa data getaran, temperature, vibrasi, flow rate, dan lain-lainnya. Perencanaan predictive maintenance dapat dilakukan berdasarkan data dari operator di lapangan yang diajukan melalui work order ke departemen maintenance untuk dilakuakan tindakan tepat sehingga tidak akan merugikan perusahaan.

E. Unplanned Maintenance (Pemeliharaan Tak Terencana)

Unplanned maintenance biasanya berupa breakdown atau emergency maintenance. Breakdown atau emergency maintenance (pemeliharaan darurat) adalah tindakan maintenance yang tidak dilakukan pada mesin peralatan yang masih dapat beroperasi, sampai mesin/peralatan tersebut rusak dan tidak dapat berfungsi lagi. Melalui bentuk pelaksanaan pemeliharaan tak terencana ini, diharapkan penerapan pemeliharaan tersebut akan dapat memperpanjang umur dari mesin/peralatan, dan dapat memperkecil frekuensi kerusakan

F. Autonomous Maintenance (Pemeliharaan Mandiri)

Autonomous maintenance atau pemeliharaan mandiri merupakan suatu kegiatan untuk dapat meningkatkan produktivitas dan efisiensi mesin/peralatan melalui kegiatan-kegiatan yang dilaksanakan oleh operator untuk memelihara mesin/peralatan yang mereka tangani sendiri. Prinsip-prinsi yang terdapat pada lima S, merupakan prinsip yang mendasari kegiatan autonomous maintenance yaitu :

$\checkmark$ Seiri (clearing up): Menyingkirkan benda-benda yang tidak diperlukan.

$\checkmark$ Seiton (organazing): Menempatkan benda-benda yang diperlukan dengan rapi.

$\checkmark$ Seiso (cleaning): Membersikan peralatan dan tempat kerja.

$\checkmark$ Seikatsu(standarizing): Membuat standar kebersihan, pelumasan dan inspeksi.

$\checkmark \quad$ Shitsuke (training and discipline): Meningkatkan skill dan moral.

\section{Reliability Centered Maintenance (RCM)}

Reliability centered maintenance sebagai suatu proses yang digunakan untuk menentukan apa yang seharusnya dilakukan untuk menjamin suatu sistem dapat berjalan dengan baik sesuai dengan fungsi yang diinginkan oleh pengguna. (Moubray, 1997). Karakteristik RCM adalah sebagai berikut:

1. Tujuan utama dari RCM adalah untuk menjaga fungsi sistem peralatan, bukan hanya menjaga peralatan agar tetap bekerja. Mengetahui fungsi sistem berarti mengetahui keluaran yang menjadi tujuan sistem dan dengan demikian dapat direncanakan tindakan perawatan untuk menjaga keluaran sistem sesuai dengan petunjuk kerja yang dimiliki peralatan.

2. Mengidentifikasi mode kerusakan spesifik dalam bagian-bagian peralatan yang potensial menghasilkan kerusakan fungsi sistem.

3. Membuat prioritas perawatan dari mode kerusakan yang terjadi. Prioritas ini berdasarkan mode kerusakan yang memberikan kontribusi terbesar dalam sistem akan mendapat prioritas tertinggi.

4. Tindakan yang telah diberi prioritas diberi tindakan pencegahan yang dapat diterapkan.

Berikut ini adalah langkah-langkah Penerapan RCM:

A. Seleksi Sistem Dan Pengumpulan Informasi

Pada saat keputusan untuk melaksanakan program RCM pada mesin atau fasilitas, maka muncul dua pertanyaan (Siswanto, 2010):

1. Pada level perakitan (komponen, sistem) proses analisis harus dilakukan?

2. Apakah keseluruhan fasilitas/mesin mendapat proses, jika tidak, pemilihan yang bagaimana yang harus dibuat?

Dalam pengumpulan informasi, waktu dan usaha dapat dipersingkat jika terdapat dokumen mengenai sistem dan informasi yang berhubungan. Daftar dokumen dan informasi yang berhubungan dengan setiap sistem untuk analisa RCM adalah:

$>$ Sistem skematik atau block diagram.

$>$ Buku manual untuk sistem yang mungkin memiliki informasi penting dari disain dan operasi sistem.

$>$ Data historis peralatan.

$>$ Sistem operasi manual, yang memiliki detail bagaimana sistem tersebut berfungsi.

$>$ Spesifikasi sistem disain.

B. Definisi Batasan Sistem 
Ada dua alasan mengapa definisi batasan sistem diperlukan dalam analisa proses RCM (Siswanto, 2010):

1. Pasti terdapat pengetahuan dari apa yang telah dan belum dimasukkan dalam sistem sehingga daftar komponen yang akurat dapat dianalisa.

2. Batasan-batasan yang akan menentukan faktor dalam menentukan apa yang masuk dan keluar dari sistem. Hal ini diperlukan pemahaman mengenai apa yang termasuk dalam sistem dan yang tidak.

C. Deskripsi Sistem Dan Blok Diagram Fungsi

Setelah seleksi sistem selesai dan batasan sistem juga selesai, maka dilanjutkan pada langkah ketiga untuk identifikasi dan mendokumentasikan detail-detail penting dari sistem. Lima item yang dikembangkan pada langkah ini adalah (Siswanto, 2010):

$>$ Deskripsi Sistem

$>\quad$ Functional Block Diagram

$>$ Sistem In/Out

$>$ Struktur Sistem Breakdown

$>$ Historis Peralatan

D. Fungsi Sistem Dan Kegagalan Fungsi

Pada bagian ini, proses analisis difokuskan pada kegagalan fungsi, bukan kegagalan peralatan. Biasanya kegagalan fungsi memiliki dua atau lebih kondisi yang menyebabkan kegagalan parsial, minor maupun mayor pada sistem (Siswanto, 2010).

E. Failure Mode And Effect Analysis

FMEA adalah suatu prosedur terstruktur untuk mengidentifikasi dan mencegah sebanyak mungkin mode kegagalan (failure mode). FMEA digunakan untuk mengidentifikasi sumber-sumber dan akar penyebab dari suatu masalah kualitas. Suatu mode kegagalan adalah apa saja yang termasuk dalam kecacatan/kegagalan dalam desain, kondisi diluar batas spesifikasi yang telah ditetapkan, atau perubahan dalam produk yang menyebabkan terganggunya fungsi dari produk itu. FMEA dapat dilakukan dengan cara (Prasetyo, 2017)

1. Mengenali dan mengevaluasi kegagalan potensi suatu produk dan efeknya.

2. Mengidentifikasi tindakan yang bisa menghilangkan atau mengurangi kesempatan dari kegagalan potensi terjadi.

3. Pencatatan proses (document the process).

Tujuan yang dapat dicapai oleh perusahaan dengan penerapan FMEA:

1. Untuk mengidentifikasi mode kegagalan dan tingkat keparahan efeknya.

2. Untuk mengidentifikasi karakteristik kritis dan karakteristik signifikan.

3. Untuk mengurutkan pesanan desain potensial dan defisiensi proses.

4. Untuk membantu fokus engineer dalam mengurangi perhatian terhadap produk dan proses, dan membentu mencegah timbulnya permasalahan.

Dalam FMEA, dapat dilakukan perhitungan RPN untuk menentukan tingkat kegagalan tertinggi. Risk priority number (RPN) merupakan hubungan antara tiga buah variabel yaitu severity (keparahan), occurrence (frekuensi kejadian), detection (deteksi kegagalan) yang menunjukkan tingkat resiko yang mengarah pada tindakan perbaikan. Adapun variabel dari RPN adalah (Siswanto, 2010):

1. Severity (X1)

Severity adalah tingkat keparahan atau efek yang ditimbulkan oleh mode kegagalan terhadap keseluruhan mesin.

2. Occurance $(\mathrm{O})$

Occurrence adalah tingkat frekuensi terjadinya kerusakan atau kegagalan. Occurence berhubungan dengan estimasi jumlah kegagalan kumulatif yang muncul akibat suatu penyebab tertentu pada mesin.

3. $\quad$ Detection (D)

Deteksi diberikan pada sistem pengendalian yang digunakan saat ini yang memiliki kemampuan untuk mendeteksi penyebab atau mode kegagalan.

F. Logic Tree Analysis

Pada bagian kolom LTA mengandung informasi mengenai nomor dan nama kegagalan fungsi, nomor dan mode kerusakan, analisis kekritisan dan keterangan tambahan yang dibutuhkan. Analisis kekritisan menempatkan setiap mode kerusakan ke dalam satu dari empat kategori. Empat hal yang penting dalam analisis kekritisan yaitu sebagai berikut:

1. Evident, yaitu apakah operator mengetahui dalam kondisi normal, telah terjadi ganguan dalam sistem?

2. Safety, yaitu apakah mode kerusakan ini menyebabkan masalah keselamatan? 
3. Outage, yaitu apakah mode kerusakan ini mengakibatkan seluruh atau sebagian mesin terhenti?

4. Category, yaitu pengkategorian yang diperoleh setelah menjawab pertanyaan-pertanyaan yang diajukan. Pada bagian ini komponen terbagi dalam 4 kategori, yakni:

$>\quad$ Kategori A (Safety problem)

$>$ Kategori B (Outage problem)

$>\quad$ Kategori C (Economic problem)

$>\quad$ Kategori D (Hidden failure)

G. Task Selection

Tugas yang dipilih dalam kegiatan preventive maintenance harus memenuhi syarat berikut:

1. Aplikatif, tugas tersebut akan dapat mencegah kegagalan, mendeteksi kegagalan atau menemukan kegagalan tersembunyi.

2. Efektif, tugas tersebut harus merupakan pilihan dengan biaya yang paling efektif diantara kandidat lainnya.

\section{Cranckshaft}

Efektifitas Crankshaft dipengaruhi oleh tekanan pelumas, temperatur pelumas serta temperatur dalam mesin dioperasiakan. Crankshaft merupakan bagian dari mesin yang menerjemahkan reciprocoating linier piston gerak ke rotasi. Crankshaft menerima beban yang besar dari torak dan batang torak serta berputar pada kecepatan tinggi dan berfungsi untuk mengubah gerak berputar yang akhirnya menggerakan roda - roda. Gerakan lurus/ bolak - balok torsk sebagai akibat tekanan gas pembakaran dirubah menjadi gerakan putar dengan perantaran batang torak.

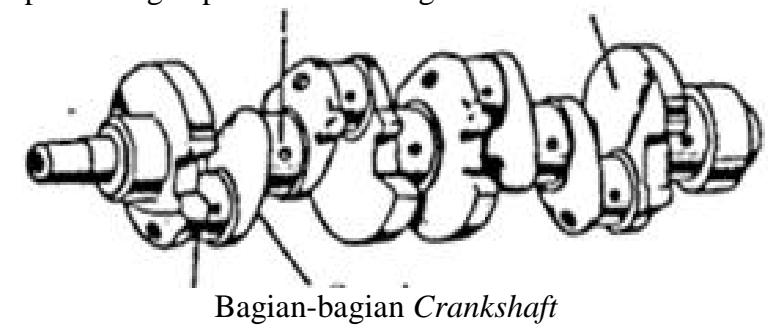

Keterangan :

Bagian-bagian Crankshaft

1. Jurnal dan Batang Torak ( Connecting rod)

- Jurnal batang torak dihubungkan dengan bantalan luncur

- Jurnal batang torak menerima langsung tekanan pembakaran

2. Jurnal Crankshaft (Crank journal)

- Didukung langsung bantalan utama dengan blok silinder

3. Bobot Balance

- Untuk menyimbang gaya - gaya yang tidak seimbang dari mekanisme Crankshaft

4. Lubang oli

- Dengan pelumasan tekan oli dari bantalan utama Crankshaft ke bantalan luncur batang torak

- Lubang di buat untuk mengurangi berat crankshaft

\section{METODE PENELITIAN}

Metode dalam penelitian ini menggunakan metode metode RCM untuk mendapatkan Risk Priority Number (RNP). Proses analisa data dengan menggunakan metode RCM memiliki bebrapa tahapan yang digunakan dalam penelitian kali ini :

1. Pemilihan Sistem dan pengumpulan Informasi.

Sistem yang dipilih adalah sistem yang memiliki frekwensi corrective maintenance yang tinggi dan biaya yang mahal dan berpengaruh besar pada kelancaran proses lingkungannya.

2. Pendefenisian Batasan Sistem.

Dilakukan untuk mengetahui apa yang termasuk dan tidak termasuk ke dalam sistem yang sedang diamati.

3. Deskripsi Sistem dan Diagram Blok Fungsi.

Bertujuan untuk mengidentifikasi dan mendokumentasikan detail penting yang sedang diamati.

4. Fungsi Sistem dan Kegagalan Fungsi.

Mengidentifikasi kegagalan fungsi dan penyebab kegagagalan pada fungsi sistem yang sedang diamati.

5. Failure Mode Effect And Analyse (FMEA). 
Merupakan tool peneitian untuk mengevaluasi potensi kegagalan yang kritis ketika sebuah kegagalan terjadi selanjutnya memutuskan apa yang dilakukan untuk mengantisispasi, mencegah, mendeteksi atau memperbaikinya. Proses analisa pada FMEA dilakukan berdasarkan hasil perhitungan rangking dimana bobot pada rangking tersebut diberikan oleh supervisior pemeliharaan PL. Poka selaku orang yang telah berpengalaman dalam melakukan perawatan terhadap mesin diesel ABC type 12V DZc.

6. Logic Tree Analysis (LTA)

Merupakan suatu pengukuran kualitatif untuk mengklasifikasikan mode kegagagalan. Pengukuran kualitatif tersebut dilakuakn oleh operator mesin dan kemudian diklasifikasikan mode kegagalan.

Berikut ini merupakan flowchart dari penelitian ini.

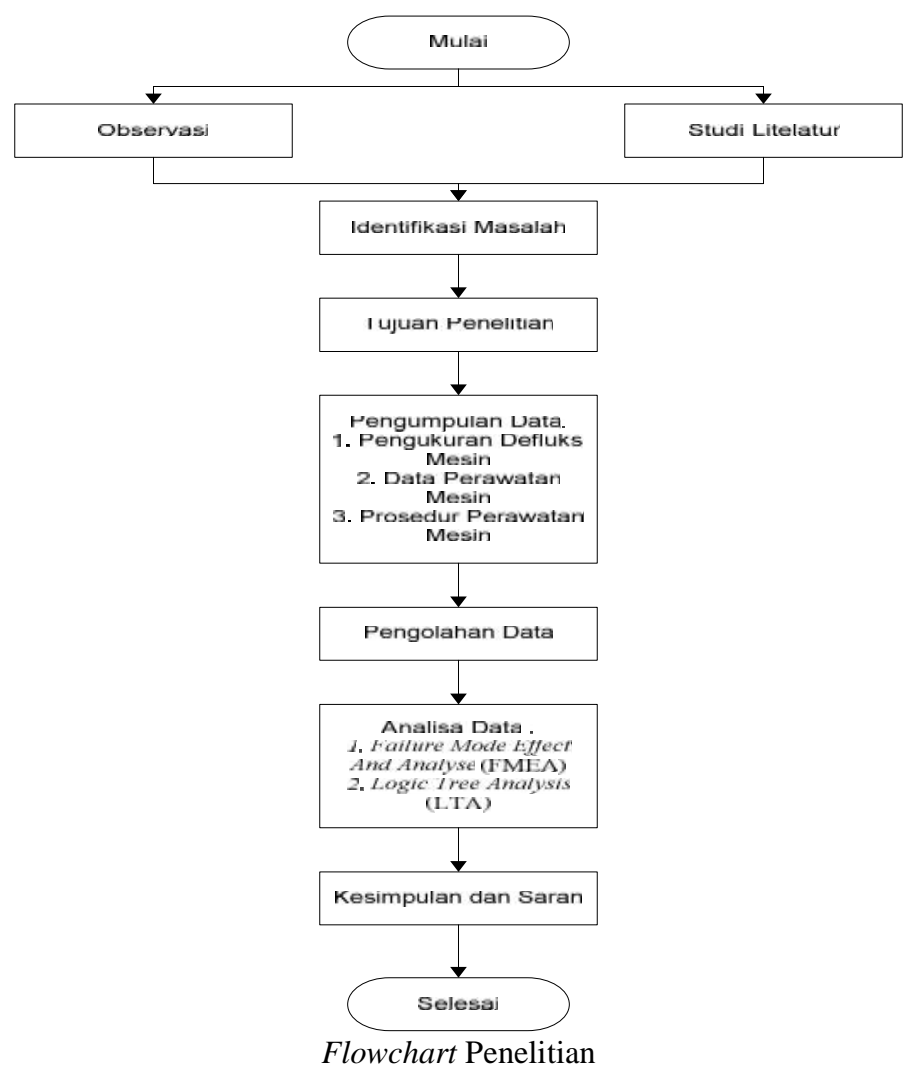

HASIL DAN PEMBAHASAN

Penentuan Mesin Kritis, Sistem / Bagian Kritis dan Komponen Kritis

Penentuan Sistem Atau Bagian Mesin Kritis Pada Mesin 4

\begin{tabular}{|c|c|c|c|c|c|}
\hline \multirow{2}{*}{$\mathbf{N}$} & \multirow[b]{2}{*}{ Nama Bagian/Sistem } & \multicolumn{2}{|c|}{ Kerusakan(kali) } & \multicolumn{2}{|c|}{ Downtime (jam) } \\
\hline & & $\mathbf{f}$ & $\%$ & $\mathbf{t}$ & $\%$ \\
\hline 1 & Cylinder Head Assy & 115 & 53,00 & 1.461 & 52,09 \\
\hline 2 & Piston Assy & 2 & 0,92 & 93 & 3,32 \\
\hline 3 & Connecting Rod Assy & 5 & 2,30 & 61 & 2,17 \\
\hline 4 & Crankshaft Assy & 3 & 1,38 & 95 & 3,39 \\
\hline 5 & Inlet and Exhaust & 10 & 4,61 & 107 & 3,81 \\
\hline 6 & Sistem Pelumasan & 13 & 5,99 & 195 & 6,95 \\
\hline 7 & Sistem Bahan Bakar & 6 & 2,76 & 72 & 2,57 \\
\hline 8 & Sistem Pembakaran & 42 & 19,35 & 489 & 17,43 \\
\hline 9 & Sistem Pendinginan & 8 & 3,69 & 88 & 3,14 \\
\hline 10 & Block Mesin & 7 & 3,23 & 86 & 3,07 \\
\hline 11 & Proteksi Mekanik & 6 & 2,76 & 58 & 2,07 \\
\hline & Jumlah & 217 & 100,00 & 2.805 & 100,00 \\
\hline
\end{tabular}

Berdasarkan data-data yang diperoleh, komponen-komponen kritis pada mesin ABC Tipe $12 \mathrm{v}$ di PT PLN (Persero) Pusat Listrik Poka yaitu cylinder head, inlet valve rocker arm, inlet valve housing, 
inlet valve, inlet valve seat, exhaust valve rocker arm, exhaust valve housing, exhaust valve, exhaust valve seat, gasket dan distribution box.

\section{Penggabungan Faktor Kualitatif dan Kuantitatif dalam RCM Decision Worksheet}

Berdasarkan pengolahan dan analisis data, proses penggabungan faktor kualitatif dan kuantitatif melalui beberarapa tahapan. Adapun faktor kualitatif meliputi fungsi komponen, kegagalan fungsi, penyebab kegagalan dan efek kegagalan. Sedangkan proses identifikasinya melalui penyusunan functional block diagram, system failure and function failure sebagai sumber dalam penyusunan failure mode and effect analysis. MTTR untuk masing-masing komponen kritis Cylinder Head Assy. Dengan menggunakan nilai Tf, Tr, MTTF dan MTTR komponen-komponen kritis Cylinder Head Assy. dan data-data biaya kerusakan serta biaya perawatan, selanjutnya dihitung initial interval (interval perawatan yang optimal) dengan keandalan dan total biaya perawatan yang minimum.

Langkah selanjutnya adalah menggabungkan faktor kualitatif dan kuantitatif dalam RCM Decision Worksheet yang digunakan sebagai sumber informasi tindakan perawatan yang akan dilakukan dengan mengacu pada proposed task. Untuk komponen-komponen kritis di PT PLN (Persero) Wilayah Maluku Dan Maluku Utara, tindakan perawatan yang diusulkan adalah combination of task antara schedule oncondition task dan schedule restoration task untuk komponen cylinder head dengan interval waktu perawatan 1.148 jam dan distribution box dengan interval waktu perawatan 1.387 jam, sedangkan schedule discard task untuk komponen inlet valve rocker arm dengan interval waktu perawatan 1.187 jam, inlet valve housing dengan interval waktu perawatan 690 jam, inlet valve dengan interval waktu perawatan 991 jam, inlet valve seat dengan interval waktu perawatan 612 jam, exhaust valve rocker arm dengan interval waktu perawatan 1.379 jam, exhaust valve housing interval waktu perawatan 763 jam, exhaust valve dengan interval waktu perawatan 732 jam, exhaust valve seat dengan interval waktu perawatan 648 jam dan gasket dengan interval waktu perawatan 2.157 jam.

\section{Dasar Penentuan Kebijakan Perawatan yang Optimal dari Komponen Mesin}

Dari hasil perhitungan ternyata nilai keandalan dapat ditingkatkan dan total biaya perawatan dari komponen-komponen kritis dapat diturunkan. Peningkatan keandalan terbesar pada komponen exhaust valve rocker arm yang sebelumnya 0,330726786 menjadi 0,549009057 dengan prosentase peningkatan sebesar 66,00\% dan yang terkecil pada komponen exhaust valve seat yang sebelumnya 0,768241438 menjadi 0,826827404 dengan prosentase peningkatan sebesar 7,63\%. Kemudian penurunan total biaya perawatan terbesar pada komponen gasket yang sebelumnya Rp. 6.492,78 per jam menjadi Rp. $3.515,85$ dengan prosentase penurunan sebesar $45,85 \%$ dan yang terkecil pada komponen exhaust valve rocker arm yang sebelumnya Rp. 20.412,43 menjadi Rp. 18.300, 12 dengan presentase penurunan $10,29 \%$. Untuk lebih jelasnnya dapat dilihat pada table 4. Sehingga TM untuk seluruh komponen kritis dapat dijadikan sebagai dasar kebijakan perawatan optimal karena berhasil meningkatkan keandalan (R) dan menurunkan total biaya perawatan (TC).

\section{Failure Mode Effect And Analyse (FMEA)}

Ada beberapa langkah penyusunan dalam penelitian menggunakan metode FMEA ini untuk menganalisa terhadap keandalan instrumentasi mesin Anglo Belgian Corporation (ABC) type 12V DZC di PT. PLN (Persero) PLTD Poka menggunakan metode FMEA ini yaitu:

1. Peninjauan kembali bagian atau komponen yang mengalami gangguan atau kegagalan pada mesin Anglo Belgian Corporation (ABC) type 12V DZC serta fungsi komponen tersebut. Langkah ini ada pada tabel worksheet FMEA untuk komponent instrument dan function.

2. Mengidentifikasi mode atau bentuk kegagalan yang terjadi pada komponen. Langkah ini ada pada tabel worksheet FMEA mesin Anglo Belgian Corporation (ABC) type 12V DZC untuk potential failure mode.

3. Mengidentifikasi akibat atau efek potensial dari masing-masing mode kegagalan yang terjadi, langkah ini ada pada tabel worksheet FMEA mesin Anglo Belgian Corporation (ABC) type 12V DZC untuk potential effect of failure.

4. Menentukan nilai saverity (keparahan) dari masing-masing komponen insrument. Kriteria saferity dijelaskan pada bab III.

5. Mengidentifikai terjadinya kegagalan pada mesin langkah ini dijelaskan pada tabel potential Causes of Failure (potensi penyebab kegagalan).

6. Menentukan laju kegagagalan dan nilai occurence (frekuensi kegagalan pada masing-masing komponen. Kriteria occurence dijelaskan pada bab III.

7. Mengidentifikasi current controls (bentuk pengendalian) pada masing-masing komponen instrumen. Current controls diartikan bagaimana cara penanggulangan dalam menyelesaikan permasalahan yang ada. 
8. Menentukan detection (deteksi) atau kemempuan dalam mendeteksi kegagalan yang terjadi. Kriteria langkah untuk detection dijelaskan pada bab III.

9. Menghitung nilai Risk Priority Number (RPN) dengan mengkalikan nilai ketiga varibel dari severity, occurence detection, dan RPN rata-rata dari masing-masing komponen instrument.

10. Penjelasan dan rangkuman dari hasil analisa instrumentasi mesin Anglo Belgian Corporation (ABC) type $12 \mathrm{~V}$ DZC menggunakan metode FMEA.

Sebagai analisa pendukung dalam metode FMEA, digunakan analisa diagram pareto untuk membuat grafik diagram pareto berdasarkan RPN rata-rata dari tabel worksheet FMEA, dan melakukan analisa ketersediaan (availability) pada instrumentasi mesin.

Worksheet FMEA pada instrumentasi mesin Anglo Belgian Corporation (ABC) type 12V DZC PT.

\begin{tabular}{|c|c|c|c|c|c|c|c|c|c|c|}
\hline \multicolumn{11}{|c|}{ PLN (Persero) area Poka } \\
\hline $\begin{array}{c}\text { NO } \\
\cdot\end{array}$ & $\begin{array}{l}\text { Component } \\
\text { Instrument }\end{array}$ & Function & $\begin{array}{c}\text { Potencial } \\
\text { Failure } \\
\text { Moda }\end{array}$ & $\begin{array}{c}\text { Potencial } \\
\text { Effect of } \\
\text { Failure }\end{array}$ & $\begin{array}{l}S \\
E \\
V\end{array}$ & $\begin{array}{c}\text { Potencial } \\
\text { Cause of } \\
\text { Failure }\end{array}$ & $\begin{array}{l}O \\
C \\
C\end{array}$ & $\begin{array}{l}\text { Current } \\
\text { Controls }\end{array}$ & $\begin{array}{l}D \\
E \\
T\end{array}$ & $\begin{array}{l}R \\
P \\
N\end{array}$ \\
\hline 1 & $\begin{array}{l}\text { Cylinder } \\
\text { Head Assy }\end{array}$ & $\begin{array}{l}\text { sebagai } \\
\text { penutup bagian } \\
\text { atas mesin dan } \\
\text { menahan } \\
\text { tekanan } \\
\text { kompresi dan } \\
\text { pembakaran, } \\
\text { mengendalikan } \\
\text { panas dalam } \\
\text { ruangan } \\
\text { (dengan sistem } \\
\text { pendingin) dan } \\
\text { sebagai } \\
\text { dudukan } \\
\text { komponen- } \\
\text { komponen } \\
\text { bagian atas } \\
\text { mesin mesin. }\end{array}$ & $\begin{array}{l}1 . \\
\text { Bocornya } \\
\text { Katup } \\
\text { Cylinder } \\
\text { 2. Katup } \\
\text { Cylinder } \\
\text { Memuai }\end{array}$ & $\begin{array}{l}\text { 1. Kinerja } \\
\text { mesin } \\
\text { menurun } \\
\text { 2. Radiator } \\
\text { dan oli } \\
\text { akan } \\
\text { tercampur }\end{array}$ & 5 & $\begin{array}{l}\text { 1. Kebocoran } \\
\text { terjadi } \\
\text { karena terlalu } \\
\text { haus } \\
\text { 2. Mesin } \\
\text { yang begitu } \\
\text { panas }\end{array}$ & $\begin{array}{l}1 \\
0\end{array}$ & $\begin{array}{l}\text { Melakukan } \\
\text { pengeceka } \\
\mathrm{n} \\
\text { atau } \\
\text { perbaikan } \\
\text { alat } \\
\text { terkait }\end{array}$ & 5 & $\begin{array}{c}25 \\
0\end{array}$ \\
\hline 2 & $\begin{array}{l}\text { Piston } \\
\text { Assy }\end{array}$ & $\begin{array}{l}\text { merubah } \\
\text { tekanan } \\
\text { pembakaran } \\
\text { menjadi } \\
\text { gerakan } \\
\text { mekanis. }\end{array}$ & $\begin{array}{l}\text { 1. Piston } \\
\text { Rusak/hau } \\
\text { s }\end{array}$ & $\begin{array}{l}\text { 1. Oli } \\
\text { mesin } \\
\text { cepat habis } \\
\text { 2. Mesin } \\
\text { Kurang } \\
\text { bertenaga }\end{array}$ & 6 & $\begin{array}{l}\text { 1. Piston } \\
\text { Assy dan } \\
\text { Head Assy } \\
\text { bertabrakan } \\
\text { 2. Kehabisan } \\
\text { oli mesin }\end{array}$ & 3 & $\begin{array}{l}\text { Melakukan } \\
\text { pengeceka } \\
\mathrm{n} \\
\text { atau } \\
\text { perbaikan } \\
\text { alat } \\
\text { terkait }\end{array}$ & 5 & 90 \\
\hline 3 & $\begin{array}{l}\text { Connecting } \\
\text { Rod Assy }\end{array}$ & $\begin{array}{l}\text { meneruskan } \\
\text { gerak naik } \\
\text { turun piston ke } \\
\text { crankshaft. }\end{array}$ & $\begin{array}{l}1 . \\
\text { Connectin } \\
\text { g Rod } \\
\text { Assy haus }\end{array}$ & $\begin{array}{l}\text { 1. Tenaga } \\
\text { mesin } \\
\text { berkurang }\end{array}$ & 5 & $\begin{array}{l}\text { 1. Kehabisan } \\
\text { oli mesin }\end{array}$ & 4 & $\begin{array}{l}\text { Melakukan } \\
\text { pengeceka } \\
\mathrm{n} \\
\text { atau } \\
\text { perbaikan } \\
\text { alat } \\
\text { terkait }\end{array}$ & 5 & $\begin{array}{c}10 \\
0\end{array}$ \\
\hline 4 & $\begin{array}{l}\text { Crankshaft } \\
\text { Assy }\end{array}$ & $\begin{array}{l}\text { berfungsi } \\
\text { merubah gerak } \\
\text { naik turun } \\
\text { piston menjadi } \\
\text { gerak putar. }\end{array}$ & $\begin{array}{l}1 . \\
\text { Crankshaf } \\
t \text { Assy } \\
\text { haus }\end{array}$ & $\begin{array}{l}\text { 1. Tenaga } \\
\text { mesin } \\
\text { berkurang }\end{array}$ & 5 & $\begin{array}{l}\text { 1. Kehabisan } \\
\text { oli mesin }\end{array}$ & 4 & $\begin{array}{l}\text { Melakukan } \\
\text { pengeceka } \\
\mathrm{n} \\
\text { atau } \\
\text { perbaikan } \\
\text { alat } \\
\text { terkait }\end{array}$ & 5 & $\begin{array}{c}10 \\
0\end{array}$ \\
\hline 5 & $\begin{array}{l}\text { Inlet dan } \\
\text { Exhaust }\end{array}$ & $\begin{array}{l}\text { berfungsi } \\
\text { memasukkan } \\
\text { udara bersih } \\
\text { untuk } \\
\text { kebutuhan } \\
\text { pembakaran di } \\
\text { dalam mesin } \\
\text { dan membuang } \\
\text { gas sisa } \\
\text { pembakaran }\end{array}$ & $\begin{array}{l}\text { 1. Terjadi } \\
\text { kebocoran } \\
2 . \\
\text { Kerusaka } \\
\text { n pipa dan } \\
\text { line }\end{array}$ & $\begin{array}{l}\text { 1. Kinerja } \\
\text { mesin } \\
\text { menurun } \\
\text { 2. Muncul } \\
\text { suara asing }\end{array}$ & 5 & $\begin{array}{l}\text { 1. Masuknya } \\
\text { material asing }\end{array}$ & 5 & $\begin{array}{l}\text { Melakukan } \\
\text { pengeceka } \\
\mathrm{n} \\
\text { atau } \\
\text { perbaikan } \\
\text { alat } \\
\text { terkait }\end{array}$ & 5 & $\begin{array}{c}12 \\
5\end{array}$ \\
\hline
\end{tabular}




\begin{tabular}{|c|c|c|c|c|c|c|c|c|c|c|}
\hline $\begin{array}{c}\text { NO } \\
.\end{array}$ & $\begin{array}{l}\text { Component } \\
\text { Instrument }\end{array}$ & Function & $\begin{array}{l}\text { Potencial } \\
\text { Failure } \\
\text { Moda }\end{array}$ & $\begin{array}{l}\text { Potencial } \\
\text { Effect of } \\
\text { Failure }\end{array}$ & $\begin{array}{l}S \\
E \\
V\end{array}$ & $\begin{array}{l}\text { Potencial } \\
\text { Cause of } \\
\text { Failure }\end{array}$ & $\begin{array}{l}O \\
C \\
C\end{array}$ & $\begin{array}{l}\text { Current } \\
\text { Controls }\end{array}$ & $\begin{array}{l}D \\
E \\
T\end{array}$ & $\begin{array}{l}R \\
P \\
N\end{array}$ \\
\hline & & $\begin{array}{l}\text { dengan } \\
\text { mereduksi } \\
\text { tekanan, panas } \\
\text { dan emisinya. }\end{array}$ & & & & & & & & \\
\hline 6 & $\begin{array}{l}\text { Sistem } \\
\text { Pelumasan }\end{array}$ & $\begin{array}{l}\text { mengurangi } \\
\text { terjadinya } \\
\text { gesekan dan } \\
\text { mencegah } \\
\text { berkaratnya } \\
\text { komponen- } \\
\text { komponen } \\
\text { mesin yang } \\
\text { bergerak } \\
\text { translasi } \\
\text { maupun rotasi. }\end{array}$ & $\begin{array}{l}\text { 1. Katup } \\
\text { pengatur } \\
\text { tekanan } \\
\text { oli rusak. } \\
\text { 2. Alat } \\
\text { pengukur } \\
\text { tekanan } \\
\text { rusak. } \\
\text { 3. sil } \\
\text { rusak }\end{array}$ & $\begin{array}{l}\text { 1. Mesin } \\
\text { Tidak } \\
\text { dapat } \\
\text { distarter }\end{array}$ & 7 & $\begin{array}{l}\text { 1. Umur } \\
\text { pakai } \\
2 . \\
\text { Pemasangan } \\
\text { yang } \\
\text { salah }\end{array}$ & 6 & $\begin{array}{l}\text { Melakukan } \\
\text { pergantian } \\
\text { komponen } \\
\text { yang rusak }\end{array}$ & 5 & $\begin{array}{c}21 \\
0\end{array}$ \\
\hline 7 & $\begin{array}{l}\text { Sistem } \\
\text { bahan } \\
\text { bakar }\end{array}$ & $\begin{array}{l}\text { menyediakan } \\
\text { bahan bakar } \\
\text { untuk } \\
\text { kebutuhan } \\
\text { kerja mesin. }\end{array}$ & $\begin{array}{l}\text { 1. Tangki } \\
\text { bahan } \\
\text { bakar } \\
\text { bocor }\end{array}$ & $\begin{array}{l}\text { 1. Mesin } \\
\text { cepat } \\
\text { kehabisan } \\
\text { bahan } \\
\text { bakar } \\
\end{array}$ & 3 & $\begin{array}{l}\text { 1. Terjadi } \\
\text { kecelakaan } \\
\text { kerja yang } \\
\text { mengakibatka } \\
n \text { benturan }\end{array}$ & 5 & $\begin{array}{l}\text { Melakukan } \\
\text { perbaikan }\end{array}$ & 5 & 75 \\
\hline 8 & $\begin{array}{l}\text { Sistem } \\
\text { Pembakara } \\
\text { n }\end{array}$ & $\begin{array}{l}\text { menyemprotka } \\
\mathrm{n} \text { bahan } \\
\text { bakar ke ruang } \\
\text { bakar dan } \\
\text { mengatur } \\
\text { ijumlah } \\
\text { bahan bakar } \\
\text { yang } \\
\text { disemprotkan } \\
\text { sesuai } \\
\text { kebutuhan dan } \\
\text { beban mesin. }\end{array}$ & $\begin{array}{l}1 . \\
\text { Kondenso } \\
\text { r rusak } \\
\text { 2. Kabel } \\
\text { Putus }\end{array}$ & $\begin{array}{l}\text { 1. Mesin } \\
\text { tidak dapat } \\
\text { hidup }\end{array}$ & 7 & $\begin{array}{l}\text { 1. Umur } \\
\text { pakai } \\
2 . \\
\text { Kecelakaan } \\
\text { kerja }\end{array}$ & 8 & $\begin{array}{l}\text { Melakukan } \\
\text { pengeceka } \\
\text { n, } \\
\text { perbaikan, } \\
\text { dan } \\
\text { pergantian } \\
\text { komponen } \\
\text { yang rusak }\end{array}$ & 6 & $\begin{array}{c}33 \\
6\end{array}$ \\
\hline 9 & $\begin{array}{l}\text { Sistem } \\
\text { Pendingina } \\
\mathrm{n}\end{array}$ & $\begin{array}{l}\text { mengurangi } \\
\text { panas yang } \\
\text { berlebihan } \\
\text { pada } \\
\text { komponen } \\
\text { mesin. }\end{array}$ & $\begin{array}{l}\text { 1. Silinder } \\
\text { Head } \\
\text { bengkok } \\
\text { 2. Pack } \\
\text { cop rusak }\end{array}$ & $\begin{array}{l}\text { 1. Oli } \\
\text { mesin } \\
\text { bercampur } \\
\text { radiator }\end{array}$ & 2 & $\begin{array}{l}\text { 1. mesin } \\
\text { terlalu } \\
\text { dipaksakan } \\
\text { hingga } \\
\text { 2. overheat }\end{array}$ & 5 & $\begin{array}{l}\text { Melakukan } \\
\text { pengeceka } \\
\mathrm{n} \\
\text { atau } \\
\text { perbaikan } \\
\text { alat } \\
\text { terkait }\end{array}$ & 5 & 50 \\
\hline 10 & $\begin{array}{l}\text { Block } \\
\text { Mesin }\end{array}$ & $\begin{array}{l}\text { rumah atau } \\
\text { tempat } \\
\text { kedudukan } \\
\text { komponen- } \\
\text { komponen } \\
\text { utama yang } \\
\text { bergerak. }\end{array}$ & $\begin{array}{l}\text { 1. blok } \\
\text { mesin } \\
\text { haus }\end{array}$ & $\begin{array}{l}\text { 1. Terjadi } \\
\text { kelonggara } \\
\mathrm{n}\end{array}$ & 5 & $\begin{array}{l}\text { 1. Kehabisan } \\
\text { oli mesin }\end{array}$ & 5 & $\begin{array}{l}\text { Melakukan } \\
\text { pengeceka } \\
\mathrm{n} \\
\text { atau } \\
\text { perbaikan } \\
\text { alat } \\
\text { terkait }\end{array}$ & 5 & $\begin{array}{c}12 \\
5\end{array}$ \\
\hline 11 & $\begin{array}{l}\text { Proteksi } \\
\text { Mekanik }\end{array}$ & $\begin{array}{l}\text { sebagai } \\
\text { penggerak } \\
\text { mula } \\
\text { dalam } \\
\text { menghidupkan } \\
\text { dan } \\
\text { menghentikan } \\
\text { kerja mesin }\end{array}$ & $\begin{array}{l}1 . \\
\text { Kerusaka } \\
\text { n batang } \\
\text { penggerak }\end{array}$ & $\begin{array}{l}\text { 1. Kinerja } \\
\text { mesin } \\
\text { berkurang }\end{array}$ & 5 & $\begin{array}{l}\text { 1. Umur } \\
\text { pakai } \\
\text { 2. Suhu yang } \\
\text { tinggi } \\
\text { 3. Terjadi } \\
\text { benturan } \\
\text { komponen }\end{array}$ & 5 & $\begin{array}{l}\text { Melakukan } \\
\text { pengeceka } \\
\mathrm{n} \\
\text { atau } \\
\text { perbaikan } \\
\text { alat } \\
\text { terkait }\end{array}$ & 5 & $\begin{array}{c}12 \\
5\end{array}$ \\
\hline
\end{tabular}

\section{Analisa Instrumental Sistem Engkol Mesin Anglo Belgian Corporation (ABC) Type} 12v Dzc

Dari analisa instrumentasi sistem engkol mesin anglo belgian corporation (abc) type $12 \mathrm{v}$ dzc dengan menggunakan metode FMEA menggunakan metode FMEA maka didapat RPN total sebesar 1586 dengan 11 komponen instrumen yang mengalami gangguan. RPN rata-rata dari komponen instrumen yaitu: Sistem Pembakaran sebesar 336, Cylinder Head Assy sebesar 250, sistem pelumasan sebesar 210, Inlet dan Exhaust sebesar 125, block mesin sebesar 125, proteksi mekanik sebesar 125, connecting rod 
assy sebesar 100. Crankshaft assy sebesar 100, piston assy sebesar 90, sistem bahan bakar sebesar 75, dan sistem pendinginan sebesar 50.

Persentase Kumulatif Instrumen Sistem Engkol Mesin Anglo Belgian Corporation (ABC)

Type 12v DZC

\begin{tabular}{|c|l|c|c|c|c|}
\hline NO. & \multicolumn{1}{|c|}{ Komponen } & $\boldsymbol{R P N}$ & $\begin{array}{c}\text { Total } \\
\text { Kumulatif }\end{array}$ & $\begin{array}{c}\text { Persentase Total } \\
\text { Keseluruhan } \\
\mathbf{\%}\end{array}$ & $\begin{array}{c}\text { Persentase } \\
\text { Kumulatif } \\
\mathbf{\%}\end{array}$ \\
\hline 1 & Sistem Pembakaran & 336 & 336 & 21.19 & 21.19 \\
\hline 2 & Cylinder Head Assy & 250 & 586 & 15.76 & 36.95 \\
\hline 3 & Sistem Pelumasan & 210 & 796 & 13.24 & 50.19 \\
\hline 4 & Inlet dan Exhaust & 125 & 921 & 7.88 & 58.07 \\
\hline 5 & Block Mesin & 125 & 1046 & 7.88 & 65.95 \\
\hline 6 & Proteksi Mekanik & 125 & 1171 & 7.88 & 73.83 \\
\hline 7 & Connecting Rod Assy & 100 & 1271 & 6.31 & 80.14 \\
\hline 8 & Crankshaft Assy & 100 & 1371 & 6.31 & 86.44 \\
\hline 9 & Piston Assy & 90 & 1461 & 5.67 & 92.12 \\
\hline 10 & Sistem bahan bakar & 75 & 1536 & 4.73 & 96.85 \\
\hline 11 & Sistem Pendinginan & 50 & 1586 & 3.15 & 100.00 \\
\hline & Total & $\mathbf{1 5 8 6}$ & & 100.00 & \\
\hline
\end{tabular}

Logic Tree Analysis (LTA)

(LTA) merupakan proses yang kualitatif yang digunakan untuk mengetahu konsekuensi yang ditimbulkan oleh masing - masing failure mode. Tujuan Logic Tree Analysis (LTA) adalah mengklasifikasikan failure mode ke dalam beberapa kategori sehingga nantinya dapat ditentukan tingkat prioritas dalam penanganan masing-masing failure mode berdasarkan kategorinya.

Logic Tree Analysis

\begin{tabular}{|c|c|c|c|c|c|c|c|}
\hline \multirow{2}{*}{ No } & \multirow{2}{*}{$\begin{array}{l}\text { Failure } \\
\text { function }\end{array}$} & \multirow{2}{*}{ No } & \multirow{2}{*}{ Failure Mode } & \multicolumn{4}{|c|}{ Criticality Analysis } \\
\hline & & & & Evident & Savety & Outage & Category \\
\hline \multirow{2}{*}{1} & \multirow{2}{*}{$\begin{array}{l}\text { Suhu } \\
\text { menjadi } \\
\text { panas }\end{array}$} & 1 & $\begin{array}{l}\text { Katup } \\
\text { Cilynder } \\
\text { bocor }\end{array}$ & Y & $\mathrm{N}$ & $\mathrm{N}$ & $\mathrm{C}$ \\
\hline & & 2 & $\begin{array}{l}\text { Katup } \\
\text { Cilynder } \\
\text { memuai } \\
\end{array}$ & $\mathrm{Y}$ & $\mathrm{N}$ & $\mathrm{N}$ & $\mathrm{C}$ \\
\hline 2 & $\begin{array}{l}\text { Kinerja } \\
\text { Mesin } \\
\text { kurang baik }\end{array}$ & 1 & $\begin{array}{l}\text { Piston } \\
\text { Rusak/haus }\end{array}$ & $\mathrm{Y}$ & $\mathrm{N}$ & $\mathrm{N}$ & $\mathrm{C}$ \\
\hline 3 & $\begin{array}{l}\text { Gerak naik } \\
\text { turun } \\
\text { mesin tidak } \\
\text { stabil }\end{array}$ & 1 & $\begin{array}{l}\text { Connecting } \\
\text { Rod } \\
\text { Assy haus }\end{array}$ & $\mathrm{N}$ & $\mathrm{N}$ & $\mathrm{N}$ & $\mathrm{D} / \mathrm{B}$ \\
\hline 4 & $\begin{array}{l}\text { Gerak } \\
\text { berputar } \\
\text { mesin tidak } \\
\text { stabil }\end{array}$ & 1 & $\begin{array}{l}\text { Crankshaft } \\
\text { Assy } \\
\text { haus }\end{array}$ & $\mathrm{N}$ & $\mathrm{N}$ & $\mathrm{N}$ & $\mathrm{D} / \mathrm{B}$ \\
\hline \multirow[b]{2}{*}{5} & \multirow{2}{*}{$\begin{array}{l}\text { Sirkulasi } \\
\text { udara } \\
\text { dalam } \\
\text { mesin } \\
\text { tidak stabil }\end{array}$} & 1 & Kebocoran & $\mathrm{Y}$ & $\mathrm{N}$ & $\mathrm{N}$ & $\mathrm{C}$ \\
\hline & & 2 & $\begin{array}{l}\text { Kerusakan } \\
\text { pipa dan line }\end{array}$ & $\mathrm{N}$ & $\mathrm{N}$ & $\mathrm{N}$ & $\mathrm{D} / \mathrm{B}$ \\
\hline \multirow[t]{2}{*}{6} & \multirow[t]{2}{*}{$\begin{array}{l}\text { Mesin tidak } \\
\text { dapat } \\
\text { distarter }\end{array}$} & 1 & $\begin{array}{l}\text { Katup } \\
\text { pengatur } \\
\text { tekanan oli } \\
\text { rusak }\end{array}$ & $\mathrm{Y}$ & $\mathrm{N}$ & $\mathrm{Y}$ & B \\
\hline & & 2 & Alat pengukur & $\mathrm{Y}$ & $\mathrm{N}$ & $\mathrm{Y}$ & $\mathrm{B}$ \\
\hline
\end{tabular}




\begin{tabular}{|c|c|c|c|c|c|c|c|}
\hline \multirow{4}{*}{ No } & \multirow{4}{*}{$\begin{array}{l}\text { Failure } \\
\text { function }\end{array}$} & \multirow{2}{*}{ No } & \multirow{2}{*}{ Failure Mode } & \multicolumn{4}{|c|}{ Criticality Analysis } \\
\hline & & & & Evident & Savety & Outage & Category \\
\hline & & & tekanan rusak & & & & \\
\hline & & 3 & Sil rusak & $\mathrm{N}$ & $\mathrm{N}$ & $\mathrm{Y}$ & B \\
\hline 7 & $\begin{array}{l}\text { Bahan } \\
\text { bakar cepat } \\
\text { habis }\end{array}$ & 1 & $\begin{array}{l}\text { Tangki bahan } \\
\text { bakar } \\
\text { bocor }\end{array}$ & $\mathrm{N}$ & $\mathrm{N}$ & $\mathrm{N}$ & $\mathrm{C}$ \\
\hline 8 & $\begin{array}{l}\text { Tidak } \\
\text { terjadi }\end{array}$ & 1 & $\begin{array}{l}\text { Kondensor } \\
\text { rusak }\end{array}$ & $\mathrm{N}$ & $\mathrm{N}$ & $\mathrm{Y}$ & B \\
\hline & pembakaran & 2 & Kabel rusak & $\mathrm{N}$ & $\mathrm{N}$ & $\mathrm{Y}$ & $\mathrm{B}$ \\
\hline 0 & $\begin{array}{l}\text { suhu mesin } \\
\text { menjadi }\end{array}$ & 1 & $\begin{array}{l}\text { Silinder Head } \\
\text { bengkok }\end{array}$ & $\mathrm{Y}$ & $\mathrm{N}$ & $\mathrm{N}$ & $\mathrm{C}$ \\
\hline & $\begin{array}{l}\text { sangat } \\
\text { panas }\end{array}$ & 2 & $\begin{array}{l}\text { pack pop } \\
\text { rusak }\end{array}$ & $\mathrm{N}$ & $\mathrm{N}$ & $\mathrm{N}$ & $\mathrm{D} / \mathrm{B}$ \\
\hline 10 & $\begin{array}{l}\text { Komponen } \\
\text { mesin } \\
\text { bergeser }\end{array}$ & 1 & $\begin{array}{l}\text { Blok mesin } \\
\text { haus }\end{array}$ & $\mathrm{N}$ & $\mathrm{N}$ & $\mathrm{N}$ & $\mathrm{D} / \mathrm{B}$ \\
\hline 11 & $\begin{array}{l}\text { Kinerja } \\
\text { Mesin } \\
\text { berkurang }\end{array}$ & 1 & $\begin{array}{l}\text { Kerusakan } \\
\text { batang } \\
\text { penggerak }\end{array}$ & $\mathrm{Y}$ & $\mathrm{N}$ & $\mathrm{N}$ & $\mathrm{C}$ \\
\hline
\end{tabular}

Keterangan: $\mathrm{Y}=\mathrm{Yes}$

$$
\begin{aligned}
& \mathrm{N}=\text { No } \\
& \mathrm{A}=\text { Tidak berdampak terhadap personal dan lingkungan } \\
& \mathrm{B}=\text { Berdampak terhadap operasional dan kerugian yang signifikan } \\
& \mathrm{C}=\text { Berdampak terhadap operasional dan kerugian yang relative kecil } \\
& \mathrm{D}=\text { hidden failure }
\end{aligned}
$$

Hasil Logic Tree Analysis yang ditunjukkan pada Tabel di atas dari total 17 failure mode menunjukkan bahwa 0\% kategori A hal ini dikarenakan Failure Mode tidak mempunyai konsekuensi safety terhadap personel maupun lingkungan, 29,4\% diantaranya adalah kategori B karena failure mode memiliki konsekuensi terhadap operasional plant yang dapat mengakibatkan kerugian ekonomi secara signifikan, 41,8\% di antaranya adalah kategori C failure mode tidak berpengaruh kepada safety maupun operasitional plant dan hanya mengakibatkan kerugian ekonomi yang relative kecil untuk perbaikan, 29,4 di antaranya adalah kategori D/B karena failure mode tergolong sebagai hidden failure yang berdampak bagi kerugian ekonomi yang relative kecil untuk perbaikan.

\section{KESIMPULAN}

Berdasarkan hasil pengolahan data dan analisis yang telah dilakukan sebelumnya dapat disimpulkan beberapa hal yaitu:

1. Komponen-komponen mesin kritis di PT PLN (Persero) Wilayah Maluku Dan Maluku Utara yaitu: cylinder head, inlet valve rocker arm, inlet valve housing, inlet valve, inlet valve seat, exhaust valve housing, exhaust valve, exhaust valve seat, gasket dan distribution box.

2. Perawatan inlet valve seat yang sebelumnya dilaksanakan setiap 30 hari menjadi 26 hari, exhaust valve seat yang sebelumnya dilaksanakan setiap 30 hari menjadi 27 hari. Inlet valve housing yang sebelumnya dilaksanakan setiap 45 hari menjadi 29 hari. Exhaust valve yang sebelumnya dilaksanakan setiap 45 hari menjadi 31 hari, exhaust valve housing yang sebelumnya dilaksanakan 45 hari menjadi 32 hari. Kemudian inlet valve yang sebelumnya dilaksanakan setiap 45 hari menjadi 41 hari, cylinder head yang sebelumnya dilaksanakan setiap 90 menjadi 48 hari, inlet valve rocker arm yang sebelumnya dilaksanakan setiap 90 hari menjadi 49 hari dan exhaust valve rocker arm yang sebelumnya dilaksanakan setiap 90 hari menjadi 57 hari. Selanjutnya, distribution box yang sebelumnya dilaksanakan setiap 105 hari menjadi 58 hari dan gasket yang sebelumnya dilaksanakan setiap 105 hari menjadi 90 hari

3. Terjadi peningkatkan keandalan pada komponen-komponen kritis. Peningkatan terbesar pada exhaust valve rocker arm yaitu: 66,00\% dan terkecil pada exhaust valve seat yaitu 7,63\%. Selain itu terjadi penurunan total biaya perawatan pada komponen- komponen kritis. Penurunan terbesar pada gasket yaitu: $45,85 \%$ dan terkecil pada exhaust valve rocker arm yaitu: 10,29\%. Dalam hal ini interval perawatan untuk seluruh komponen kritis dapat dijadikan dasar kebijakan perawatan yang optimal di PT PLN (Persero) Wilayah Maluku Dan Maluku Utara. 


\section{DAFTAR PUSTAKA}

Al-Ghamdi, (2005)., Reliability Centered Maintenance Concepts and Applications: A Case Study, Univ. Cincinnati Industrial Engineering, International Journal of Industrial Engineering-Theory Applications and Practice; Pp: 123-132; Vol: 7

Arsyad, M., \& Sultan, A. Z. (2018). Manajemen Perawatan. Deepublish

Ebeling, E. Charles, (1997), An Introduction to Reliability and Maintainability Engineering, Mc.GrawHill, Singapore.

Govil, A. K, (1993)., Reliability Centered Maintenance, Mc. Graw Hill Publishing Co, New Delhi

Havard, J. Thevik. (2000). Determination of Cost Optimal Predetermined Maintenance, schedule (on line), (http://www.dnv.com/binari/determi nation cost optimum/ tcp4-8724.pdf). Tanggal akses 16-12-2019

Higgins, Lindley R. (1987)., Maintenance Engineering Handbook. 4th Edition. McGraw Hill Book Company. New York.

Kusumoningrum, L. (2010)., Perencanaan Perawatan Mesin Induction Furnace dengan Pendekatan Reliability Centered Maintenance (RCM). S-1 Teknik Industri, Unuversitas Pembangunan Nasional "Veteran" Yogyakarta.

Moubray, John, (1997), Reliability Centered Maintenance II, 2nd Edition, Butterworth Heinemann,Oxford.

Prasetyo, C. P. (2017)., Evaluasi Manajemen Perawatan dengan Metode Reliability Centered Maintenance (RCM) II pada Mesin Cane Cutter 1 dan 2 di Stasiun Gilingan PG Meritjan-Kediri. Rekayasa, 10(2), 99-107

Silva, Carlos Manuel I, (2008)., Proactive Reliability Maintenance: a case study conserning maintenance service cost. Journal of Quality in Maintenance Engineering, Vol. 14 No.4 pp. 343-355.

Siswanto, Y. (2010)., Perancangan Preventive Maintenance Berdasarkan Metode Reliability Centered Maintenance (RCM) Pada PT. Sinar Sosro. S-1 Teknik Industri, Universitas Sumatera Utara, Medan 
